\title{
Issues and Challenges for the Development of the Knowledge Economy in Sub-Saharan Africa
}

\author{
Jonathan S. Mbwambo ${ }^{1,2}$ \\ 1.Inter-University Council for East Africa, P.O.Box 7110, Kampala, Republic of Uganda \\ 2.College of Social Sciences and Humanities, \\ P.O. Box 3035 Chuo Kikuu, Morogoro, Tanzania
}

\begin{abstract}
Africa and particularly Sub-Saharan Africa has the lowest tertiary gross enrolment ratio globally, significantly lower than South Asia. This low enrolment is happening at the time when the population of the region is growing at unprecedented rates creating a population age structure dominated by young people under the age of 25 years. Unfortunately, the high population growth rate is not corresponding to the level of adequate human capital required for economic growth. For the region to gain from its youthful population, there must be concerted efforts to enhance productivity through education and skills development. In other words, governments in the region must ensure that the growth in the youthful population must be such that they are capable of contributing to the economy through productive jobs. While higher education institutions in the continent, continue to fall short in number of students they enroll and the quality and relevance of training they offer. This paper argues that both the number, length and quality of schooling in Africa is responsible for low economic growth. The paper proposes that unless investment in higher education is enhanced, countries in the Sub Saharan Africa will not attain requisite economic growth commanded by knowledge in science, technology and innovation. The paper recommends that since higher education generally has a greater effect on development outcomes, there is a need for develop policies and strategies to ensure investment in higher education is given high priority.
\end{abstract}

Keywords: Knowledge economy, Sab-Saharan Africa, higher education

DOI: $10.7176 / \mathrm{JEP} / 10-17-06$

Publication date:June $30^{\text {th }} 2019$

\subsection{Introduction}

Today, with nearly $70 \%$ of college students in the United States attending public universities, the percentage of students attending universities in Africa remains the lowest. At an average of $4.3 \%$ annual growth in higher education, Africa and particularly Sub-Saharan Africa has the lowest tertiary gross enrolment ratio globally, significantly lower than South Asia (Gandhi, 2018). This low enrolment is happening at the time when the population of the region is growing at unprecedented rates creating a population age structure dominated by young people under the age of 25 years.

Unfortunately, the high population growth rate is not corresponding to the level of adequate human capital required for economic growth. The World Economic Forum's Human Capital Index reported in 2017 that SubSaharan Africa captures only $55 \%$ of its human capital potential compared to the global average of $65 \%$. Thus, unlike Asia whose demographic dividend contributed $25-35 \%$ to the Tigers economic growth in the $1980 \mathrm{~s}$, Africa is yet to effectively utilize its demographic potential for economic growth and subsequent transformation of livelihoods.

For the region to gain from its youthful population, there must be concerted efforts to enhance productivity through education and skills development. In other words, governments in the region must ensure that the growth in the youthful population must be such that they are capable of contributing to the economy through productive jobs. Once provided with education and skills, the young people can be gainfully employed and hence become a catalyst for socio-economic transformation.

However, the demand for enhanced provision of skills in the continent is faced by many constraints. While institutions in the continent as reported by Johanson and Adam (2004) and WEF, (2017), continue to fall short in the assessment of their relevance to economic and social needs and their effectiveness in developing skills, it is not clear how the level of investments in higher education affects the overall potential for the development of the knowledge economy in the continent. Using literature and data from Human Development Reports, this paper shows how years of schooling have directly impacted on low Gross National Income per capita and argues that without concerted efforts to commit more funding in higher education, the continent will not be able to grows as expected.

This paper is divided into three sections sections. Following this introduction is a section on the analysis of the role of higher education in enhancing and sustaining productivity. Using data on enrolment, this section shows how low enrolment in the region has affected the overall productivity of the region. This section succinctly shows that higher education in the region is yet to impart effectively in productivity in the area. The third section of this paper looks into the creation of the knowledge economy as a means for enhanced 
productivity. This section looks into a comparative analysis of knowledge variables and ends with a presentation on existing spending in higher education. The last part of the article recommends a model for the development of higher education based on the lessons learned from the project.

\subsection{Theoretical background}

Economic development, defined here as the increase in national production of goods and services, is a complex process, and economists have had a difficult time identifying the factors that determine whether it occurs. Centuries ago Adam Smith (1776) identified "the acquired and useful abilities of all the inhabitants or members of the society," what is now called "human capital," as one of the four types of fixed capital that contribute to production in a national economy.

Some economists including Schultz (1961) while studying the incidence of poverty in poor countries observed that lack of human capital is the main factor explaining lack of development in poor countries. Using evidence from economic recovery of rich countries after the Second World War, Schultz (1961) theorized that a nation's capability to productively use physical capital is a function of its level of human capital and that if human capital does not increase along with physical capital, then economic development cannot proceed.

Based on what was theorized by Schulz, it can generally be concluded that investment in human capital is beneficial for growth. However, recent scholars including Margison et al., (2013) have looked at the type of human capital required and recommended that investment in science, technology, engineering and mathematics (STEM) than general education yield the greatest returns.

Looking at the importance of STEM, Marginson et al., (2013) concludes that there is consistent linkage between skills in STEM with the development of research as well as industrial innovation. This paper adopts the reasoning provided by Marginson et al., (2013) that for countries to develop, there must be efforts to develop human capital with effective capabilities in science, engineering, technology and mathematics.

\subsection{The state of the economy in the East African region}

The review of economic growth in the East Africa has indicated that the East African region has reached an impressive growth averaging 6\% annual GDP growth in 2016. This growth implies that there is growing economic activity taking place, an increased exchange in the volume and value of goods and services traded. Moreover, the proclaimed growth rate is a proof that the region has finally made a structural shift in its economies and hence higher prospects for changed livelihoods.

But even as the economies of the EAC have been growing, this growth has been accompanied by a growth in inequality in virtually all countries. In other words, while the East Africa States are proud of their economic prosperity, not all citizens of East Africa have seen or felt the benefits of these impressive GDP growth figures. In many cases and as evidenced from Table 1, life has become much bleaker and the highly pronounced economic boom has not generated the wealth that it was expected to produce. Put more bluntly, the growth in the East African has been met with growing poverty and inequality as presented in Table 1.

Table 1: Poverty and inequality in the East African Region

\begin{tabular}{|l|l|l|l|l|}
\hline \multirow{2}{*}{ Country } & \multicolumn{2}{|l|}{ Poverty $-\%$ of Population } & Inequality: \% of income going to the:- \\
\cline { 2 - 5 } & At $\$ 1.90$ a day PPP & $\begin{array}{l}\text { At } \$ 3.20 \text { a day } \\
\text { PPP }\end{array}$ & $\begin{array}{l}\text { Top 25\% of the income } \\
\text { distribution }\end{array}$ & $\begin{array}{l}\text { Lowest 25\% of the } \\
\text { income distribution }\end{array}$ \\
\hline Burundi & $32.4 \mathrm{a}$ & $53.2 \mathrm{a}$ & 46.7 & 6.6 \\
\hline Ethiopia & $29.6 \mathrm{~b}$ & & $29.8 \mathrm{~b}$ & \\
\hline Rwanda & $60.4 \mathrm{a}$ & $81.5 \mathrm{a}$ & 57.1 & - \\
\hline Tanzania & 48.8 & 28.2 & - & 6.4 \\
\hline Uganda & 34.6 & 66.6 & 48.3 & \\
\hline
\end{tabular}

Source: AfDB Statistics

World Bank, WDI, 2017. Poverty Head Count Ratio (\% of the population at \$1.90 a day, $2011 \mathrm{PPP}$ )

National Poverty Line

One of the key factor that have contributed to increased inequality in the region is low participation rate of the people and especially young people in the major economic activities because of lack of skills and capacity to produce and sale commodities for local and regional markets.

The level of skills and especially high-level skills in the East African region is comparatively very low as reflected from data in higher education enrolment rate illustrated by Figure 1. 


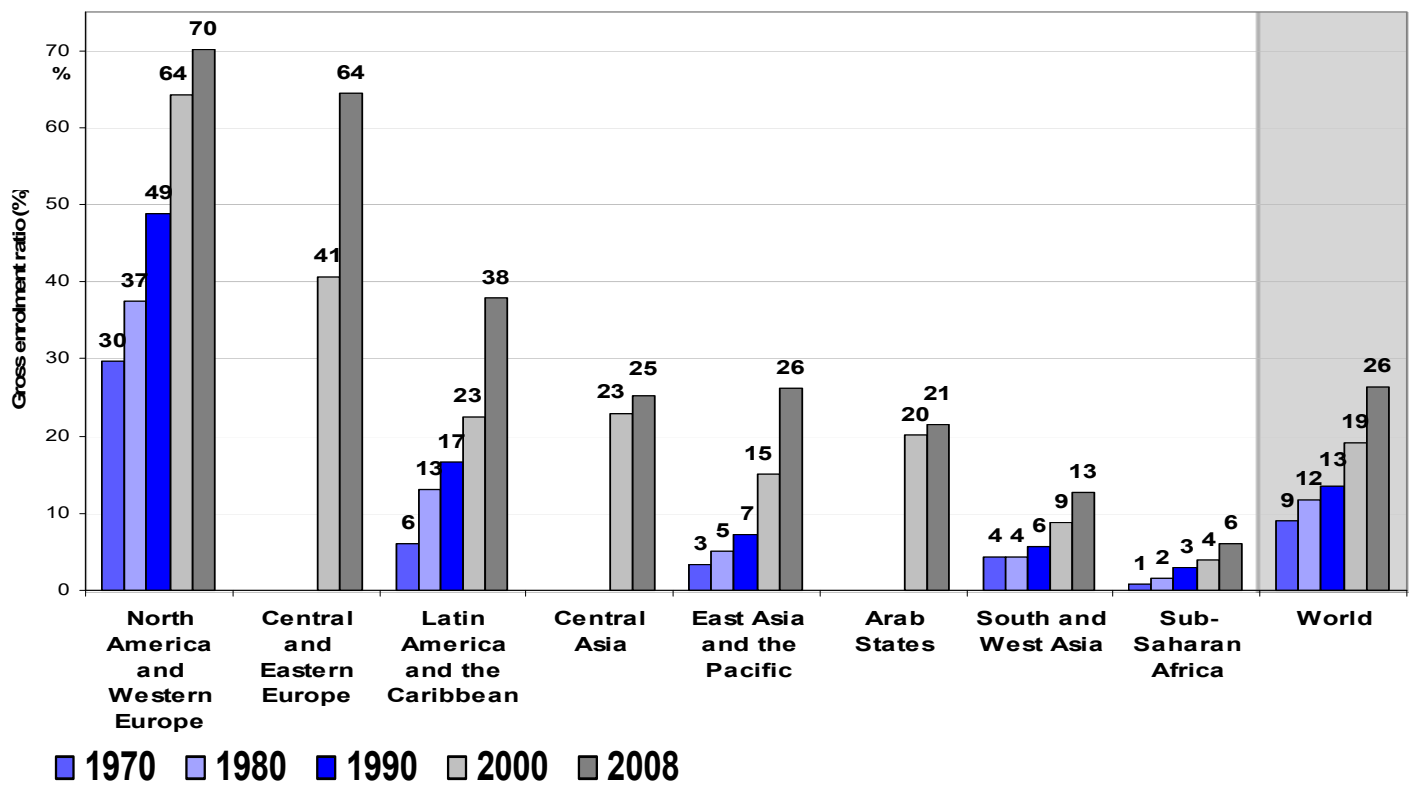

Figure 1: Gross enrolment ratio by region

Sources: UNESCO Institute for Statistics (GED 2010).

Comparing to other regions, access to higher education in East Africa is low averaging around 4\%. As results of low levels in skills development along with other factors, the level of unemployment is low as presented in Table 2 .

Table 2: Growth and employment dynamics in East Africa

\begin{tabular}{|l|l|l|l|}
\hline \multirow{2}{*}{ Country } & GDP Per Person employed (2011 PPP\$) & Unemployment (age $>15$ years, \% of the population \\
\cline { 2 - 4 } & 2015 & 2016 & 2016 \\
\hline Burundi & $1,502.0$ & $1,451.4$ & 17.7 \\
\hline Ethiopia & $3,342.4$ & $3,455.8$ & 21.6 \\
\hline Kenya & $8,390.0$ & $8,583.1$ & 38.8 \\
\hline Rwanda & $3,400.0$ & 3485.6 & 17.0 \\
\hline Sudan & $16,022.0$ & $16,055.4$ & 24.1 \\
\hline Tanzania & $5,799.5$ & $6,034.5$ & 17.9 \\
\hline Uganda & $3,971.5$ & $4,020.1$ & 17.0 \\
\hline East Africa & $6,082.2$ & $6,193.1$ & 36.1 \\
\hline
\end{tabular}

Source: AfDB, 2018: East Africa Economic Outlook.

The high incidence of unemployment presented corresponds theoretically very well with what is claimed by Wolf and Gittleman (1993) and Seetanah and Teeroovengadum (2017). The two authors, in their work relating productivity and levels of education, shows that increased higher qualification is accompanied by an annual increase in the output between $0.4 \%$ and 0.63 . As seen in the next section, productivity increases with increased level of skills associated with years of schooling.

\subsection{The relationship between years of schooling and income}

Regression analysis on the relationship between years of schooling and Gross National Income per capita from 186 countries around the world shows clearly that there is significant relationship between Gross National Income Per Capital and years of schooling as presented in Figure 2. 


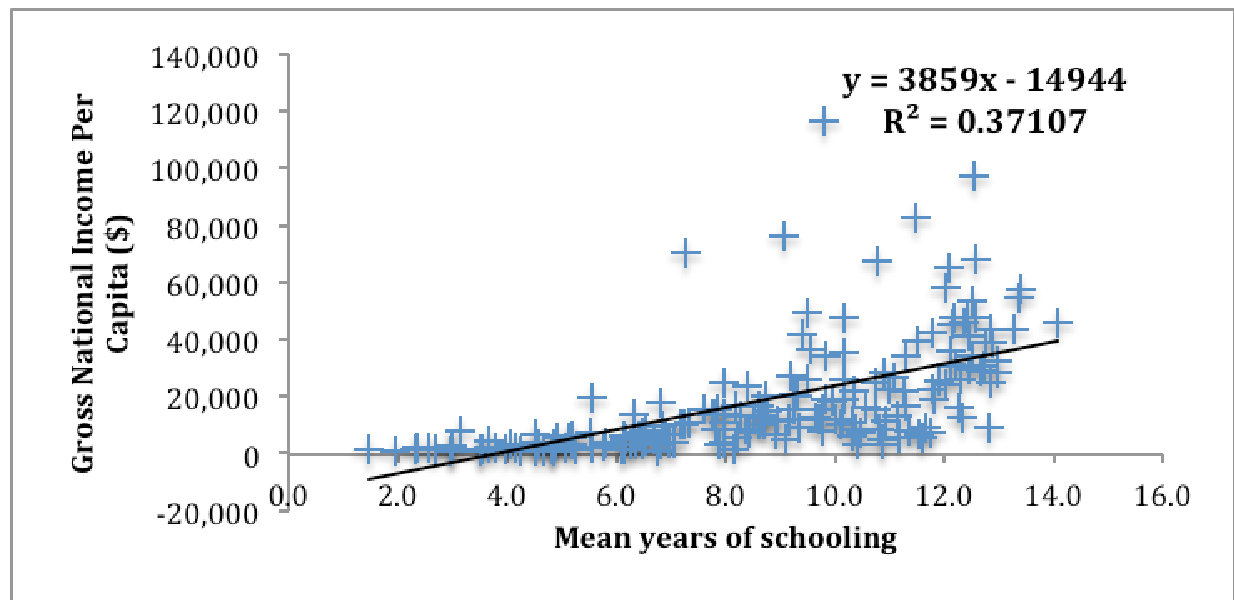

Figure 2: Relationship between years od schooling and income.

The higher income that results from increased years of schooling may be referred to as "education premium." Research shows that this premium has grown over time and as seen from Figure 2 increases with years of schooling. Thus, combining what is presented in Figure 2 and Figure 3, it is not surprising to see that countries in the eastern and southern African are ranked low with respect to Human Development Indicators (Table 3).

Table 3: Human Development Groups

\begin{tabular}{|l|l|l|}
\hline Human Development Groups & Mean year of schooling & Gross National Income Per Capita (\$) \\
\hline Very High Human Development & 12.2 & 40,041 \\
\hline High Human Development & 8.2 & 14,999 \\
\hline Medium Human Development & 6.7 & 6,849 \\
\hline Low Human Development & 4.7 & 2,521 \\
\hline
\end{tabular}

\section{Source: Human Development Report, 2018.}

Thus, there is a more significant potential that the development or rather the investment in higher education in the Eastern and Southern Africa would result in substantial economic transformation. Put simply, the East and Southern Africa must strive to build the requisite human capacity geared towards the development of knowledge and skills.

Knowledge is both an economic output and inputs that strengthens industrial processes. In this case and as Leon (2017) argued, the ability of any nation to remain competitive in a globalized environment depends on its ability to produce high value-added goods and services based on the available intellectual capital. Unfortunately, the intellectual capital is only nurtured in the university and research and development institutions.

\subsection{Creation of the Knowledge economy in the region}

Beginning with a comparative assessment of the knowledge economy measured through knowledge assessment methodologies, this section looks at the extent to which Africa and particularly Sub-Saharan Africa compares itself with what is happening in other continents.

Based on the Knowledge Assessment Methodology (KAM) developed by the World Bank in 1999, Africa and more so Sub-Saharan Africa has the lowest levels in the production and utilization of knowledge for economic development. Looking at content creation across the World (Table 4), it is evident that the region needs to enhance investment in the development and utilization of knowledge.

As Table 3 shows, developing countries occupy the nethermost of the index with Sub-Saharan Africa ranking the lowest. However, while region is indicated to score low in content creation, recent studies on knowledge economy in Africa suggest that the continent is starting to amalgamate with or may be in its way to transmute itself into a knowledge economy.

Table 4: Comparative assessment of content creation in the world

\begin{tabular}{|l|l|l|l|l|}
\hline SN & Country & Academic Articles & Collaboration coding & Domain creation \\
\hline 1 & Europe & 38.8 & 39.6 & 40.4 \\
\hline 2 & North America & 27.6 & 38.9 & 36.6 \\
\hline 3 & Asia & 22.6 & 12.7 & 14 \\
\hline 4 & Latin America/Caribbean & 3.6 & 4.3 & 4.8 \\
\hline 5 & Oceania & 3.2 & 3.1 & 2.6 \\
\hline 6 & Middle East/North Africa & 3.1 & 0.7 & 1 \\
\hline 7 & Sub-Saharan Africa & 1.1 & 0.5 & 0.7 \\
\hline
\end{tabular}


With average spending in education approaching 20\% (Figure 3), there is a high potential for Africa to grow into a knowledge economy.

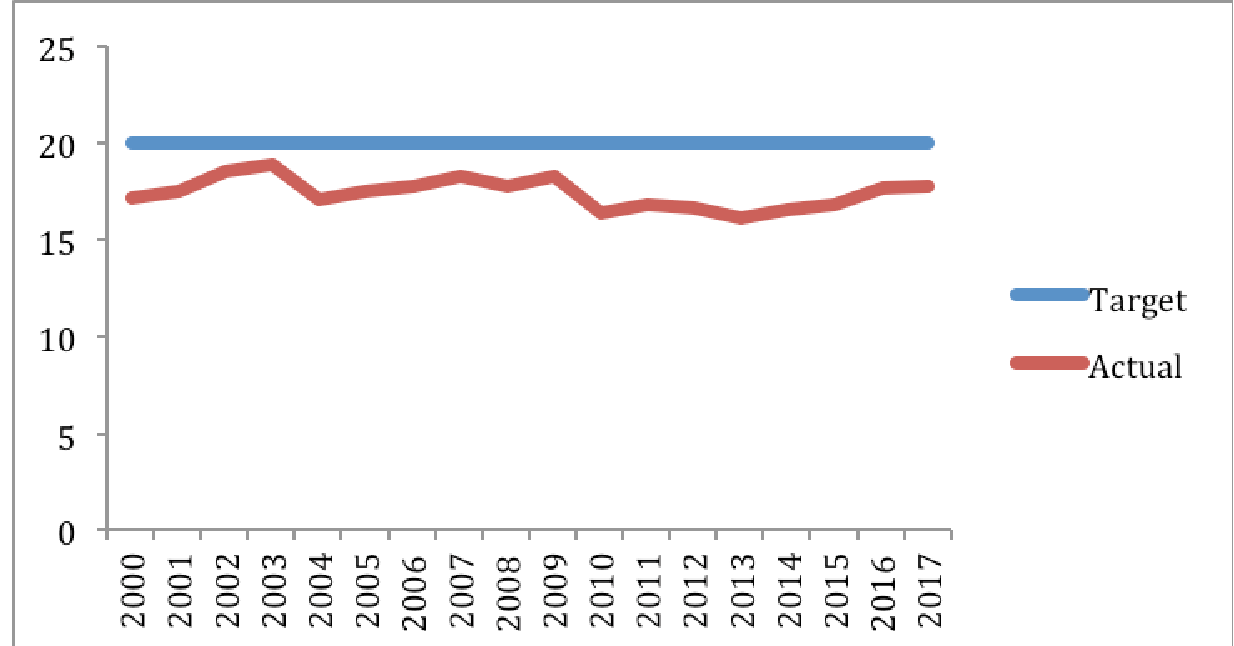

Figure 3: Government expenditure on education in East and Southern (\% of GDP)

However, looking at the distribution of spending in education as presented in Figure 4, the share of the expenditure in middle and high skills provided in university and technical institutions are comparatively low.

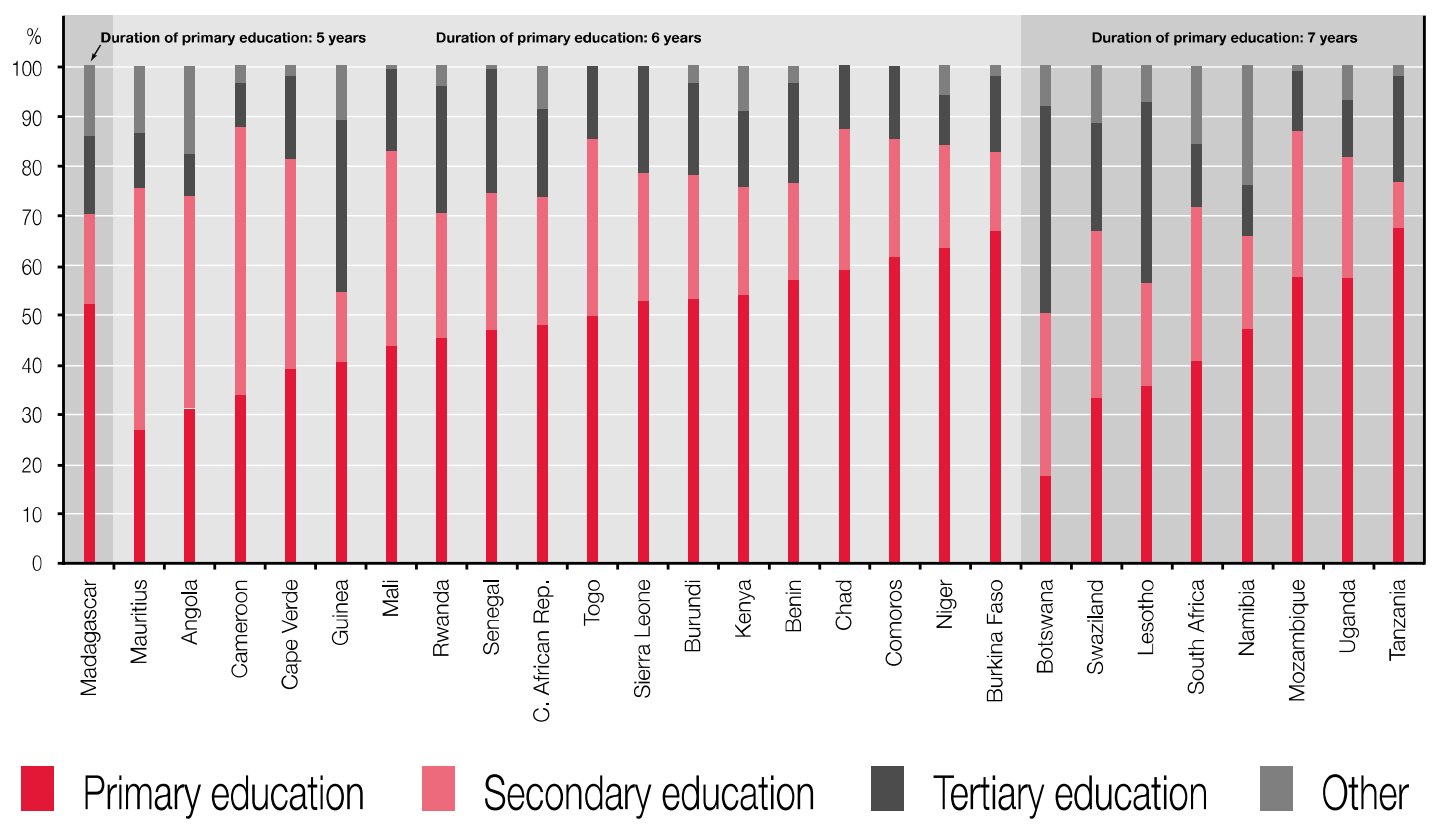

Figure 4: Allocation of Public Education Expenditure by Level of Education (Source: UNESCO Statistics)

While it is strategically correct to invest in primary or basic education, it is important to note that investment in primary education alone do not bring about the necessary impact for economic development because of the inherent relationship between years of schooling and per capita income. This is simply because primary and secondary level of education have different economic outcomes. For example, it is unlikely that primary education plays the same role in producing and bonding national leaders to guide the process of economic growth and transformation. In other words, higher levels of education tend to have larger development impacts than lower levels of education

This argument is supported by an inherent relationship between the level of human development and the percentage of population undertaking tertiary education. As Figure 5 shows, countries with high Human Development Index has more that $70 \%$ of their population with tertiary education. In contrast, countries with low Human Development Index of which most are found in Sub-Saharan Africa have only 9\% of their population with tertiary education as presented in Figure 5. 


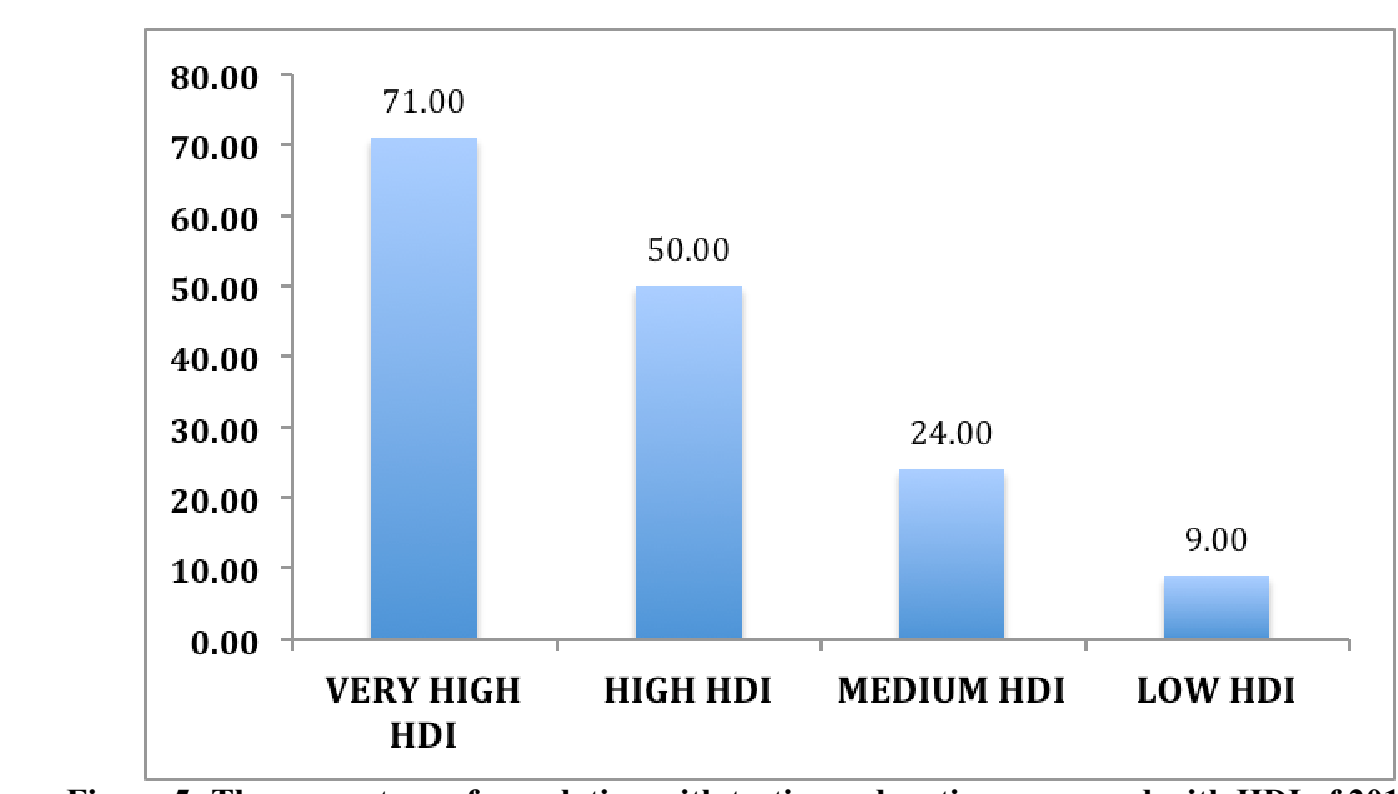

Figure 5: The percentage of population with tertiary education compared with HDI of 2017. Source: Author's calculation from HDI, 2017.

With low percentage of people with tertiary education, Africa has a limited potential to build institutions and practices known as a National Innovation System necessary for the development of knowledge producing population and organizations for economic transformation.

\section{Conclusion and recommendation}

The conclusion that education generally has a significant impact on development outcomes in Africa suggests that policy makers should invest in more education for the citizens of their countries. This is especially the case in Africa where levels of educational attainment is very low. Besides the broader general effect of education on development outcomes, the finding that higher education generally has a greater effect on development outcomes suggest that African policy makers should continue to invest more in higher education than they currently do.

\section{Reference}

Bagley, S.S., and Portnoi, L.M. (2014). Setting the Stage: Global competition in higher education. New Direction for Higher Education, 2014 (168), 5-11. https://doi.org/10.1002/he.20109.

Baumann, C. (2017). Managing processes of Globalization. Comparative, 27 (3-4), 186-202.

Boopen Seetanah and Viraiyan Teeroovengadum (2017). Higher Education and Economic Growth: Evidence from Africa. IISES 8th Economics and Finance Conference, London. http://www.iises.net/prooceedings/8th-economics-finance-conference-london

DFID (2018). East Africa Regional Analysis of Youth Demographics. Ukaid. Pp. 66. John

Dhruv Gandhi (2019). Figures of the Week: Higher Education Enrolment In SSA along with disparities in enrolment by income. Brooking Series, January 10, 2018.

Evan G. Mense, Pamela A. Lemoine, Christopher J. Garretson and Michael D. Richardson (2018). The Development of Global Higher Education in a World of Transformation. Journal of Education and Development Vol. 2. No.3. pp 47-60.

Hanushek, E. A (2011). How much do educational outcomes matter in OECD Countries?. Economic Policy, 26 (67). Pp 427-91

Hanushek, E. A (2012). Do Better Schools Lead to More Growth? Cognitive Skills, Economic Outcomes, and Causation. Journal of Economic Growth, 17(4). Pp 267-321.

Hanushek, E. A (2016). Will higher education improve economic growth?. Oxford Review of Economic Policy, Volume 32, Number 4. Pp 538-552

Hanushek, E. A., and L. Woessmann (2015). The Knowledge Capital of Nations: Education and the Economics of Growth. Cambridge, MA: MIT Press.

Kauppinen, I. (2014). Different meaning of 'knowledge as commodity' in the context of higher education. Critical Sociology 40 (3), 393-409. https://doi.org/10.1177/0896920512471218.

Nadia Hanif and Noman Arshed (2016). The relationship between school and education and economic growth: SAAEC Countries. International Journal of Economics and Financial Issues. Pp 294-300.

Nicolas Cook; Alexis Ariefg; Luren Plods Blanchard, Brocj R. William and Tomas Hustet (2018). Sub-Saharan Africa: Key issues, Challenges, and the US response. 
Ramon-Diana Leone (2017). Measuring the Knowledge Economy: A National and Organizational Perspective. Journal of Management Dynamics in the Knowledge Economy. Vol. 5 No. 2 pp 227-249.

Richard K. Johanson and Arvil V. Adams (2004). Skills Development in Sau-Saharan Africa. World Bank Regional and Sectoral Studies. Washinton DC. http://documents.worldbank.org/curated/en

Schultz, Theodore W., 1961, "Investment in Human Capital," American Economic Review, v51, n1, 1-17

Society for International Development (SID) (2016). State of East Africa Report Consolidating Misery? The Political Economy of Inequalities in East Africa. ISBN 978-9966-1912-2-9

Spring J. (2014). Globalization of Education: An Introduction. Newyork, NY: Routledge. https//doi.org/10.4324/97813115975843.

Wolf, E. and Gittleman, M (1993). The Role of Education and Productivity Convergence: Does Higher Education Matter?. In: Boopen Seetanah and Viraiyan Teeroovengadum (2017). Higher Education and Economic Growth: Evidence from Africa. IISES 8th Economics and Finance Conference, London. http://www.iises.net/prooceedings/8th-economics-finance-conference-london

World Economic Forum 2017: The future of Jobs and Skills in Africa. Preparing the Region for the Fourth Industrial Revolution. WEF.

\section{About the author}

Dr. Jonathan Stephen Mbwambo is a Regional Coordinator for the African Centers of Excellence Project (ACE II) based at the Inter-University Council for East Africa, Kampala, Uganda. Before joining the project, Dr. Mbwambo worked as an Assistant Director and a National Coordinator for the Education and Skills for Productive Jobs Project in the Department of Higher Education, Ministry of Education, Science and Technology. Dr. Mbwambo is employed as A Senior Lecturer at the College of Social Sciences and Humanities of Sokoine University of Agriculture in the United Republic of Tanzania.

As an academic, Dr. Mbwambo has a Master of Science degree in Natural Resources Management and a PhD in Development Studies. Dr. Mbwambo has supervised more than 25 Masters and PhD students in areas related to poverty, climate change, food security and Agro biodiversity. Dr. Mbwambo has published in both national and international Journals with a focus on natural resources management, food security, climate change, poverty and rural development. 